\section{Micro-method for the estimation of calcium by AutoAnalyser ${ }^{1}$}

\author{
M. R. WILlS AND B. C. GRAY From the Depart- \\ ment of Chemical Pathology, Bristol Royal \\ Infirmary, Bristol
}

The standard AutoAnalyser technique for the determination of calcium in plasma or other biological materials is based on the photometry of calcium murexide. Using this method we have been unable to obtain sufficient sensitivity to measure accurately the calcium content of plasma. Other disadvantages of this method include base-line drift due to instability of murexide, and considerable contamination from sample to sample. Moreover, the estimation involves the diffusion of calcium across a semi-permeable membrane, and the diffusion rate of calcium from an aqueous standard differs from that of a protein-containing solution such as plasma.

Wieme and van Raepenbusch (1962) described an AutoAnalyser method using plasmacorinth B instead of murexide, based on the manual method of Kingsley and Robnett $(1957,1958)$. We have increased the sensitivity of their method by eliminating the $37^{\circ} \mathrm{C}$. water-bath, by using a more favourable wavelength, and by employing a $15 \mathrm{~mm}$. flow cuvette. The plasmacorinth $\mathbf{B}$ concentration has been reduced to lower the blank value. These modifications permit the estimation of calcium concentration in $0.2 \mathrm{ml}$. of plasma. The method is also suitable for the estimation of calcium concentration in both urine and faeces. We have confirmed that interference by magnesium and phosphate is very small.

\section{REAGENTS}

All the distilled water used was further purified by deionization.

$4 \% \mathrm{w} / \mathrm{v}$ SODIUM HYDROXIDE This solution contains $0.4 \% \mathrm{w} / \mathrm{v}$ AP 14 surface-active agent (I.C.I.).

Plasmacorinth B STOCK SOLUTION (200 mg./100 ml.) Plasmacorinth B (G. Gurr), $500 \mathrm{mg}$., is dissolved in about $200 \mathrm{ml}$. of distilled water, containing $0.75 \mathrm{ml}$. of $0.1 \mathrm{~N}$ hydrochloric acid, with vigorous stirring for about one hour, and then made up to $250 \mathrm{ml}$. with distilled water. Stored in a dark bottle at room temperature the solution is stable for at least three months.

PLASMACORINTH B WORKING SOLUTION (40 mg./100 ml.) Plasmacorinth B stock solution, $20 \mathrm{ml}$., is diluted to $100 \mathrm{ml}$. with distilled water with the subsequent addition of $0.5 \mathrm{ml}$. of $0.1 \mathrm{~N}$ hydrochloric acid. Stored in a dark bottle at room temperature this solution is stable for one week. This quantity is sufficient for 90 minutes running time.

${ }^{1}$ AutoAnalyser is the trade name of Technicon Instruments Co. Received for publication 10 January 1964.
CALCIUM STANDARD STOCK SOLUTION (400 mg./100 ml.) We use a solution of Specpure calcium chloride, supplied ready made by Johnson, Matthey \& Co. Ltd. ${ }^{2}$

CALCIUM STANDARD INTERMEDIATE STOCK SOLUTION (100 mg. $/ 100 \mathrm{ml}$.) Stock standard, $50 \mathrm{ml}$., plus $1.0 \mathrm{ml}$. of concentrated hydrochloric acid, diluted to $200 \mathrm{ml}$. with distilled water is stored in a refrigerator.

CALCIUM STANDARD WORKING SOLUTIONS Dilute 10,15 , 20 , and $25 \mathrm{ml}$. volumes of intermediate stock solutions to $200 \mathrm{ml}$. with distilled water, to give working standards of $5,7 \cdot 5,10$, and $12.5 \mathrm{mg} . / 100 \mathrm{ml}$. respectively. Store in a refrigerator.

\section{PREPARATION OF SPECIMENS}

BLOOD Heparinized plasma (10 units sodium heparin $/ \mathrm{ml}$. blood) or serum may be used.

URINE When the urine is received in the laboratory, a representative sample of $25 \mathrm{ml}$. is taken and 2 drops of glacial acetic acid (A.R.) added to give a final $p H$ of approximately 3 .

FAECES A timed collection of faeces is thoroughly homogenized with the addition of distilled water as necessary and then weighed. A sample corresponding to a one-hour collection is weighed into a $250 \mathrm{ml}$. conical flask and $25 \mathrm{ml}$. of concentrated nitric acid added. The flask is then boiled in a fume cupboard until the solution appears clear. After cooling add $25 \mathrm{ml}$. of distilled water and adjust the $p \mathrm{H}$ to approximately 5 by indicator paper, adding first $40 \% \mathrm{w} / \mathrm{v}$ sodium hydroxide solution very slowly, followed by $\mathrm{N}$ sodium hydroxide solution for the final adjustment. Filter through a Whatman no. 44 paper into a $100 \mathrm{ml}$. volumetric flask and make up to volume with distilled water.

\section{DILUTION OF SPECIMENS}

This is best carried out with two syringe pipettes of capacity 0.2 and $1.0 \mathrm{ml}$.

STANDARD AND PLASMA $0.2 \mathrm{ml}$. is added to $1.0 \mathrm{ml}$. of distilled water; final dilution $1 / 6$.

URINE AND FAECES $\quad 0.2 \mathrm{ml}$. is added to $2.0 \mathrm{ml}$. of distilled water; final dilution $1 / 11$.

If the reading is less than that of the $5.0 \mathrm{mg} . / 100 \mathrm{ml}$. standard, the estimation is repeated using $0.4 \mathrm{ml}$. sample in the case of plasma (dilution $1 / 3.5$ ) and $1 \mathrm{ml}$. of distilled water in the case of urine and faeces (dilution 1/6).

\section{PROCEDURE}

The manifold is illustrated in Figure 1. The colorimeter uses a pair of $623 \mathrm{~m} \mu$ filters, and a density filter combined with the no. 1 aperture. This density filter was constructed from $x$-ray film of a sufficient density to allow a baseline setting of $23 \%$ transmission to be obtained with

2Johnson Matthey \& Co. Ltd., 78 Hatton Garden, London, E.C.1 


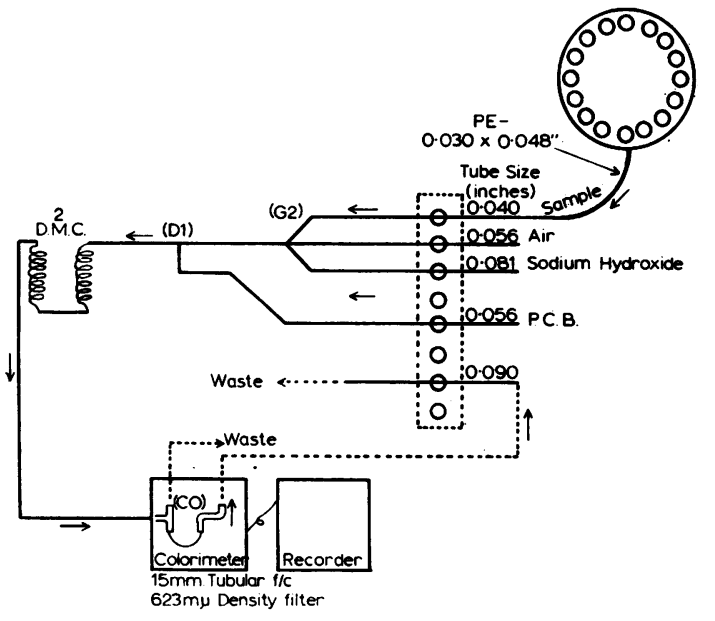

FIG. 1. Flow diagram.

the percentage transmission control at a setting between 8 and 9. The density filter can be permanently fixed to the no. 1 aperture. The wavelength of $623 \mathrm{~m} \mu$ was chosen for the filters as this represented the maximum difference between plasmacorinth $B$ and its calcium complex, as shown by their spectrophotometric absorption curves (Fig. 2). With the reagents flowing and with the sample lead in distilled water the baseline is set at $23 \%$ transmission, and this is the baseline used for the measurement of all the peaks. The baseline obtained when sampling air is lower than the 'true' baseline, due to the decrease in dilution of the colour reagent. The clearance between samples is good and the prompt and complete return to baseline is shown in Figure 3. The recorder is set to 'normal' and the samples are run at a rate of 40 per hour. The four calcium standard solutions are placed in the first and last four cups and a $\vec{F}$ $10.0 \mathrm{mg} . / 100 \mathrm{ml}$. standard sample after every six unknowns. The sensitivity should be such that the $12.5 \mathrm{mg}$. $/ 100 \mathrm{ml}$. 을 calcium standard solution reads greater than $90 \%$ 을 transmission; if necessary a variation in transmission can $\frac{\bar{\omega}}{7}$ be obtained by small variations in baseline setting. On $\odot$ our machine a baseline setting of $23 \%$ transmission

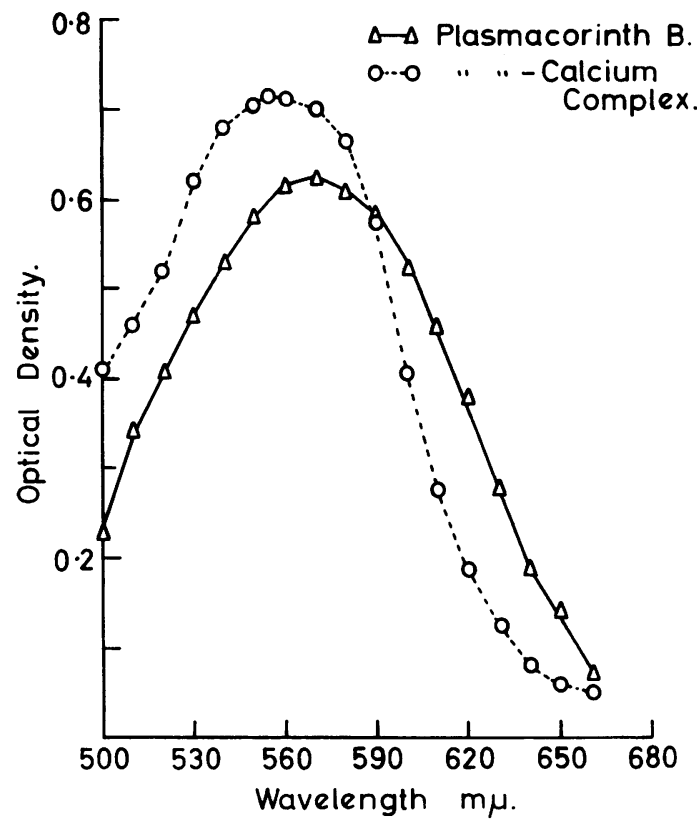

FIG. 2. Spectrophotometric absorption curves of plasmacorinth $B$ and its calcium complex.

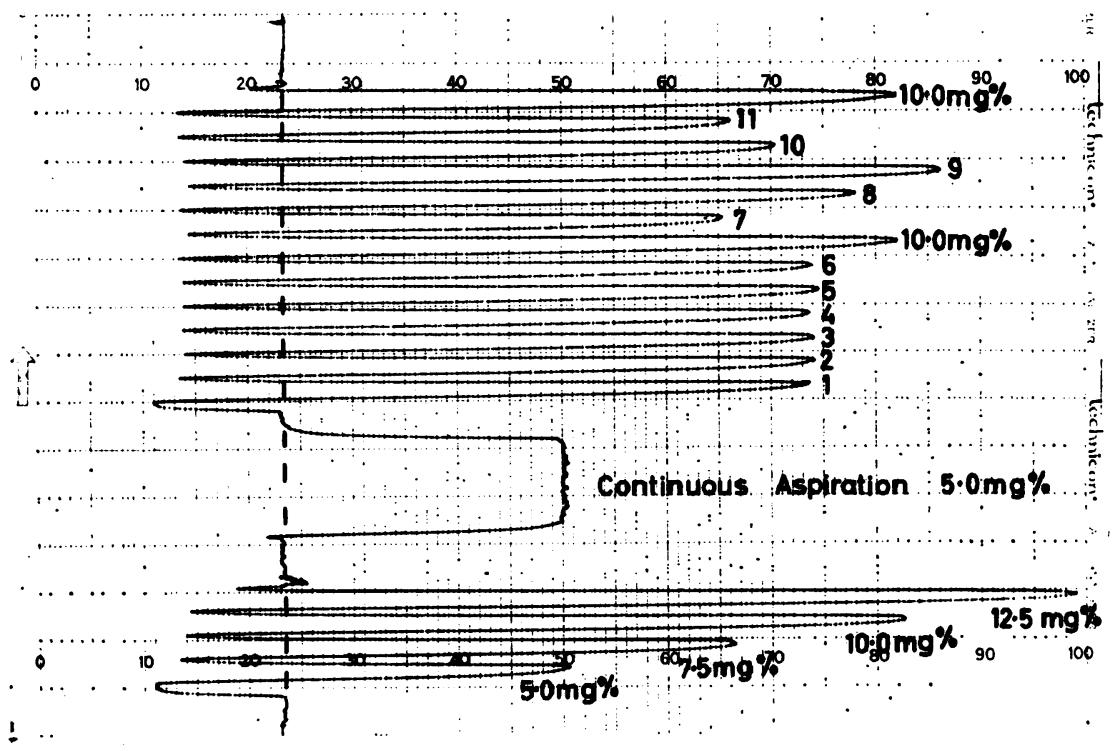

FIG. 3. Unretouched photograph of recording showing calibration, continuous aspiration of $a$ standard solution, reproducibility of pooled plasma samples (1-6), and typical plasma results (7-11). 
gives excellent sensitivity which is reproducible from day to day. Contamination from sample to sample in our system is negligible and it is therefbre unnecessary to include water washes between samples.

\section{RESULTS}

The calibration curve is linear between 5.0 and 12.5 mg./100 ml. (Fig. 4). The sensitivity of the method permits

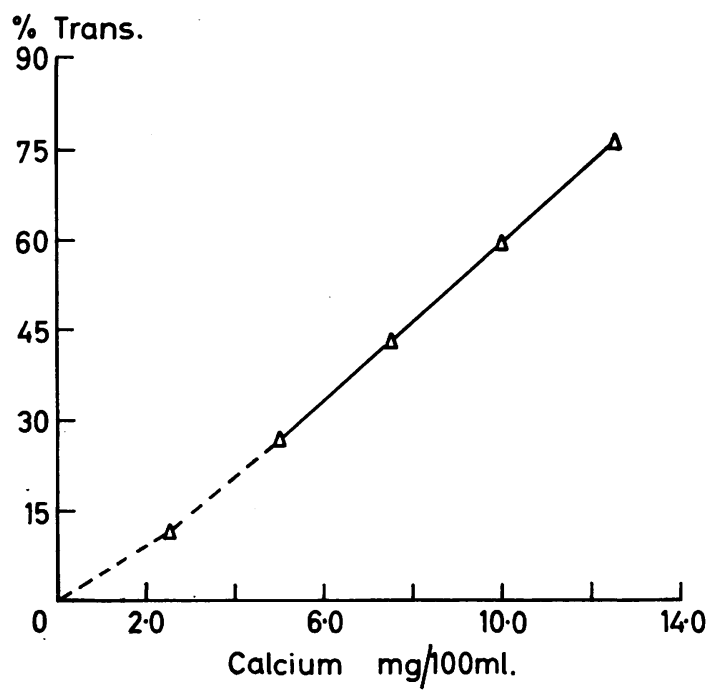

FIG. 4. Calibration curve.

the chart to be read to $0 \cdot 1 \mathrm{mg} . / 100 \mathrm{ml}$. (0.5\% transmission). The reproducibility of plasma samples and standards is within $0.2 \mathrm{mg}$. calcium $/ 100 \mathrm{ml}$. and the recovery of calcium added to plasma, urine, and faeces is between 92 and $104 \%$ (Table I). Comparison of the results obtained on 24 plasma samples (range 7.5 to 11.0 $\mathrm{mg} . / 100 \mathrm{ml}$.) and 20 urine samples (range 5.0 to 30.0 mg./100 ml.) with this method and with the E.D.T.A. titration method of Fales (1953) has shown differences within the range of $\pm 0.2 \mathrm{mg} . / 100 \mathrm{ml}$. for plasma specimens and $\pm 0.5 \mathrm{mg} . / 100 \mathrm{ml}$. for urine specimens. The mean values for the specimens tested by this method were $9.40 \mathrm{mg} . / 100 \mathrm{ml}$. for plasma and $10.40 \mathrm{mg} . / 100 \mathrm{ml}$.
TABLE I

RESULTS

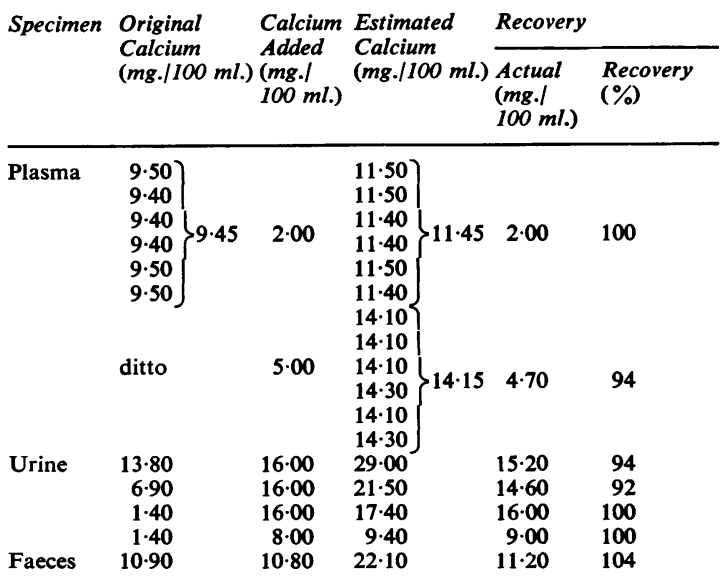

for urine as compared with $9.57 \mathrm{mg} . / 100 \mathrm{ml}$. and $10 \cdot 10$ $\mathrm{mg} . / 100 \mathrm{ml}$. respectively using the method of Fales.

The possible interference of magnesium, phosphate, and bilirubin was investigated by substituting a solution of magnesium chloride, potassium dihydrogen phosphate, and bilirubin in $0 \cdot 1 \mathrm{~N}$ sodium hydroxide for the distilled water diluent. An increase in magnesium equivalent to $5.0 \mathrm{mg} . / 100 \mathrm{ml}$. of plasma increased the apparent calcium level by less than $0.2 \mathrm{mg} . / 100 \mathrm{ml}$. An increase of phosphate concentration by the equivalent of $10.0 \mathrm{mg}$. $/ 100 \mathrm{ml}$. of plasma decreased the apparent calcium level by less than $0.2 \mathrm{mg} . / 100 \mathrm{ml}$. Bilirubin levels equivalent to $5.0 \mathrm{mg}$./ $100 \mathrm{ml}$. of plasma produced an apparent decrease of the calcium level of $0.2 \mathrm{mg} . / 100 \mathrm{ml}$. and a level equivalent to $35.0 \mathrm{mg} . / 100 \mathrm{ml}$. plasma an apparent decrease of 0.5 mg. calcium $/ 100 \mathrm{ml}$.

We are grateful to Dr. G. K. McGowan for advice and help in the preparation of this report.

\section{REFERENCES}

Fales, F. W. (1953). J. biol. Chem., 204, 577.

Kingsley, G. R., and Robnett, O. (1957). Amer. J. clin. Path., 27, 223. ,$--\frac{1}{2}$ (1958). Ibid., 29, 171.

Wieme, R. J., and van Raepenbusch, F. R. (1962). Clin. chim. Acta, 7,883 . 